\title{
Social Welfare Houses as a total institution
}

\section{Dom pomocy społecznej jako instytucja totalna}

\author{
Andrzej Borowski \\ Department of Sociology and Social Works, Faculty of Education and Philosophy, \\ Pomeranian University in Słupsk, Westerplatte St. 64, 76-200 Słupsk, Poland \\ E-mail address: aubor@poczta.onet.pl
}

\begin{abstract}
House of social welfare is a place, people live in which from different respects in families strip capability of life. Determination of house of social equipment functioned as a closed total institution in sociology, which is place of stay of number of certain person isolated on longest period from the rest of society. Each self-governed unit leading stationary institution of social welfare should process program of serviceman of gradual liquidation or limitation of meaning of physical barrier and symbolic barrier on direct enclosing this institution.
\end{abstract}

Keywords: House of social welfare; total institutions; physical and symbolic barriers; local government

\section{STRESZCZENIE}

Dom Pomocy Społecznej jest miejscem, w którym mieszkają ludzie z różnych względów pozbawieni możliwości życia w swoich rodzinach. W socjologii funkcjonuje określenie domu pomocy społecznej jako instytucji zamkniętej /totalnej/, która jest miejscem pobytu pewnej liczby osób odizolowanych na dłuższy okres od reszty społeczeństwa. Każda jednostka samorządowa prowadząca stacjonarne instytucje pomocy społecznej/np. DPS/ powinna opracować program służący stopniowej likwidacji lub ograniczeniu znaczenia barier fizycznych i symbolicznych wewnątrze i w bezpośrednim otoczeniu tych instytucji.

Stowa kluczowe: dom pomocy społecznej, instytucja totalna, bariery fizyczne i symboliczne, samorząd terytorialny

\section{WPROWADZENIE}

Dom Pomocy Społecznej jest miejscem, w którym mieszkają ludzie z różnych względów pozbawieni możliwości życia w swoich rodzinach, wśród swoich najbliższych. Są chorzy bezradni nie umieją prosić o pomoc a jednocześnie pomocy bardzo jej oczekują.

Charakter owej pomocy jest zasadniczo różny od tej, której udziela się ludziom chorym w szpitalu, przychodni czy sanatorium. Po okresie choroby osoby przebywające w tych 
placówkach wracają do swoich domów, rodzin, zakładów pracy i pełnią w nich na ogół dotychczasowe funkcje i role.

\section{ROLA DOMÓW POMOCY SPOLECZNEJ}

Dla mieszkańca DPS dom taki jest z reguły ostatnią ,przystanią” w życiu. Fakt ten szczególnie powinien mobilizować organa prowadzące do stworzenia w każdym $\mathrm{z}$ domów możliwie najlepszych warunków pobytu dla jego pensjonariuszy. Ażeby mieszkańcom DPS przywrócić szansę w miarę pełnego życia trzeba wiedzieć jak im skutecznie pomóc. Trzeba umieć te osoby pielęgnować zarówno pod względem potrzeb fizjologicznych jak i psychicznych ale również i społecznych. Sfera fizjologiczno- biologiczna zawiera odniesienie do funkcjonowania podstawowych układów organizmu ludzkiego, sfera psychiczna zawiera /zgodnie z A. Maslowem/ potrzeby bezpieczeństwa, akceptacji, afiliacji, godności i szacunku, wiedzy i rozumienia, samorealizacji i potrzeby estetyczne. Sfera społeczna zawiera role społeczne pełnione przez pensjonariusza w DPS, kontakty osobiste w ramach DPS i poza nim oraz kontakty korespondencyjne.

„Skazanie” osoby umysłowo upośledzonej na DPS jest najczęściej wyrokiem pozostawania w izolacji przez całe życie. DPS ogranicza w znacznej mierze możliwości indywidualnego rozwoju podejmowania pracy zdobycia własnych środków materialnych czy spędzania wolnego czasu zgodnie z własnymi zainteresowaniami. DPS, który nie jest placówką stymulującą wszechstronne zaspokajanie potrzeb podopiecznych może jednak realizować zasady integracji społecznej. Do realizacji tego celu potrzebne byłoby wszechstronne zdiagnozowanie pensjonariuszy oraz odejście od statusu DPS jak instytucji zamkniętej. Jeśli osoba umieszczona w nim ma być przygotowywana do życia w normalnym społeczeństwie musi mieć z nim kontakt. Dalszym etapem integracji jest stopniowe wprowadzanie samodzielnych wyjazdów do rodzin, znajomych lub sympatii, z którymi pensjonariusze korespondują. Te spotkania przybliżą mieszkańcom często nierealny świat najbardziej osobistych marzeń o kimś bliskim i własnym szczęściu. Efekt postulowanych działań można rozpatrywać w dwóch kategoriach: humanitarnych/stworzenie szansy ma aktywność życiową adekwatną do potrzeb pensjonariuszy/, ekonomicznych/ zmniejszenie obciążenia społeczeństwa kosztami utrzymania DPS [1].

O wprowadzeniu integracji decyduje wyeliminowanie lub zredukowanie barier architektonicznych i urbanistycznych, zapewnienie świadczeń i usług rehabilitacyjnych, ustawodawstwo, możliwości finansowe. Uwzględnienie tych wszystkich warunków przy wprowadzaniu w życie idei integracji nie może odbywać się w oderwaniu od sytuacji społeczno-ekonomicznej w kraju i wynikających z niej ograniczeń. Coraz bardziej istotne staje się podmiotowe traktowanie mieszkańców, posiadanie przez nich własnych przedmiotów, ubrania i miejsca na ich przechowywanie, prowadzenie aktywnego trybu życia, przełamywanie izolacji i monotonii życia w DPS.

Tymczasem tworzenie DPS z dużą liczbą mieszkańców utrudnia dokładne poznanie wszystkich podopiecznych i możliwość indywidualnego rozwiązywania ich problemów. Dzięki kontaktom ze społecznością lokalną następuje u mieszkańców DPS wzrost poczucia własnej wartości i poprawa ich zdrowia psychicznego. Zwiększa się poczucie przynależności do szerszej grupy społecznej. Placówki stacjonarne, jakimi są DPS muszą pozostać otwarte.

Instytucjonalna pomoc nie może tworzyć środowiska zamkniętego sztucznie, w którym tylko pozornie, a nie faktycznie panuje domowa atmosfera. Współistnienie ludzi chorych i zdrowych przynosi dobre efekty dla środowiska, w którym zanikają spotkania sąsiedzkie i 
tradycje kulturowe. Takie współistnienie jest przede wszystkim dobre dla tych ludzi, dla których dotąd świat poza bramą DPS- wydawał się już być zamknięty twierdzi S. Pierzynowski [2].

$\mathrm{Na}$ przełomie lat osiemdziesiątych i dziewięćdziesiątych przemianowano większość resortowych domów dla zasłużonych pracowników na DPS-y. Zraniono w ten sposób dumę wielu ludzi. Tabliczka z nazwą instytucji określa cały świat mieszkańca, determinuje jego tożsamość oraz kształtuje pryzmat przez który postrzegają go inni, a co za tym idzie jak go traktują. Dom Rencisty czy Seniora, Emeryta bądź Zasłużonego kojarzy się z czymś co wzbudza szacunek, a DPS to to samo co przytułek, dla niechcianych, odrzuconych, niekochanych przez nikogo. Nie można namawiać człowieka do podjęcia aktywności pozbawiając go jednocześnie poczucia bezpieczeństwa zauważa A. Zaniewska [3].

\section{DPS JAKO INSTYTUJCA TOTALNA}

W socjologii funkcjonuje określenie domu pomocy społecznej jako instytucji zamkniętej/ totalnej/, która jest miejscem pobytu pewnej liczby osób odizolowanych na dłuższy okres od reszty społeczeństwa, pozostających w podobnym położeniu, których zachowanie jest pod prawie całkowitą kontrolą personelu danej instytucji [4].

Według E. Goffmana autora tego pojęcia w społeczeństwie występują rozmaite instytucje totalne które można podzielić na kilka grup z których jedna w szczególny sposób dotyczy sfery działania służb socjalnych.

W polskiej rzeczywistości społecznej zaliczyć do tej sfery można między innymi instytucje takie jak Domy Pomocy Społecznej, Domy Dziecka, schroniska dla bezdomnych, noclegownie i przytuliska/. Osoby przebywające w instytucjach totalnych niezależnie od własnych słabości bądź określonych wymiarów niepełnosprawności mają do pokonania w zależności od rodzaju i typu instytucji od kilku do kilkunastu dodatkowych barier.

Podstawowe bariery występujące $\mathrm{w}$ instytucjach totalnych można podzielić na:

A) Bariery fizyczne:

a) naturalne:

- lądolód, pustynia, las, wysokie góry

- woda

- głębia morska, ziemia

- przestrzeń kosmiczna

b) sztuczne:

- zasieki z drutu kolczastego, siatka, uniform, obroża

- krata, żywopłot, płot,

- drzwi, mur, most zwodzony

B) Bariery symboliczne:

- regulamin pobytu, żargon

- ostracyzm, stygmatyzacja, izolacja psychiczna/ wyuczona bezradność/

- izolacja medyczna/kwarantanna/,izolacja religijna/klauzura/, izolacja prawna/ zakaz wstępu/, izolacja społeczna/ brak łączności i dostępu do informacji z zewnątrz $[5,8]$.

Oczywiście w Domach Pomocy Społecznej występują tylko niektóre bariery spośród wymienionych. Aby było ich mniej ważna jest współpraca administracji domów z samorządem lokalnym/ będącym z reguły organem prowadzącym dany DPS [6]. 
Od 1989r. wzrasta systematycznie zarówno ilość domów pomocy społecznej jak i ilość przebywających w nich pensjonariuszy. W związku z prognozami demograficznymi/ starzenie się polskiego społeczeństwa/ ilość ta $\mathrm{w}$ najbliższych latach $\mathrm{w}$ związku $\mathrm{z}$ niekorzystnymi tendencjami demograficznymi będzie nadal systematycznie wzrastać. Tendencje te przedstawia opracowana na podstawie danych statystycznych poniższa Tabela 1

Tabela 1. Dynamika funkcjonowania DPS-ów po zmianie systemowej.

\begin{tabular}{|c|c|c|c|c|}
\hline Rok & ilość DPS & miejsca w DPS & pensjonariusze DPS & oczekujący \\
\hline 1989 & 609 & 67439 & 64821 & 13460 \\
\hline 1990 & 629 & 68020 & 65760 & 13426 \\
\hline 1991 & 695 & 69701 & 67054 & 9190 \\
\hline 1992 & 712 & 71691 & 68686 & 10287 \\
\hline 1993 & 765 & 75383 & 71747 & 8450 \\
\hline 1994 & 811 & 78417 & 74653 & 8906 \\
\hline 1995 & 831 & 79898 & 76487 & 10453 \\
\hline 1996 & 872 & 81333 & 78405 & 11974 \\
\hline 1997 & 938 & 83488 & 80453 & 12867 \\
\hline 1998 & 960 & 83692 & 81950 & 12378 \\
\hline 1999 & 904 & 78961 & 77656 & 10298 \\
\hline 2000 & 936 & 81655 & 80634 & 9372 \\
\hline 2001 & 983 & 86184 & 85240 & 13706 \\
\hline 2002 & 999 & 88325 & 87500 & 16568 \\
\hline 2003 & 1099 & 99700 & 91800 & 19800 \\
\hline 2004 & 1154 & 96090 & 93930 & 8573 \\
\hline 2005 & 1196 & 97515 & 93372 & 6960 \\
\hline 2006 & 1255 & 99130 & 94418 & 6703 \\
\hline 2007 & 1313 & 101101 & 96696 & 7560 \\
\hline 2008 & 1334 & 100832 & 98416 & 9606 \\
\hline 2009 & 1398 & 102500 & 99900 & 8300 \\
\hline 2010 & 1421 & 102947 & 101199 & 9453 \\
\hline 2011 & 1514 & 105405 & 101949 & 10444 \\
\hline
\end{tabular}

Analizując marginalizujący charakter instytucji pomocy społecznej M. Oliwa Ciesielska podkreśla, że obecny model opiekuńczości w Polsce trudno uznać za poprawny, gdyż coraz trudniej zabezpieczyć potrzeby poszczególnych osób, które wcześniej wykreowano na biernych beneficjentów. Aby do takiej sytuacji nie dochodziło potrzebny jest w każdej jednostce samorządowej prowadzącej stacjonarne instytucje pomocy społecznej/np. DPS/ program służący stopniowej likwidacji lub ograniczeniu znaczenia poszczególnych barier/ 
fizycznych i symbolicznych/. Dobrym krokiem w tym kierunku wydaje się być publikowany przez Stowarzyszenie Auxilio Venire Katalog Domów Pomocy Społecznej [7].

Szczególnie ważne dla omawianych przeze mnie kwestii wydaje się być zawarta $\mathrm{w}$ katalogu krótka charakterystyka poszczególnych obiektów, uwzględniająca m.in. istniejące bariery architektoniczne i naturalne.

\section{WNIOSKI}

Samorządy lokalne nie powinny w swoich planach inwestycyjnych zapominać o konieczności podejmowania działań na rzecz redukcji również barier fizycznych i symbolicznych w Domach Pomocy Sołecznej. Likwidacja barier symbolicznych jest zadaniem o wiele trudniejszym i pracochłonnym niż likwidacja barier architektonicznych i naturalnych jednak społeczne efekty takich działań są bardziej dalekosiężne i sprzyjają pozytywnemu odbiorowi tych instytucji przez pensjonariuszy i osoby odwiedziające.

\section{References}

[1] S. Wałkiewicz, Praca socjalna 2 (1987) 28-31.

[2] S. Pierzynowski, Praca socjalna 3 (1997) 21-46.

[3] A. B. Zaniewska, Tematy 10 (1995) 14-17.

[4] K. Olechnicki, P. Załęcki: Słownik socjologiczny, Toruń, 1997, s. 85.

[5] A. Borowski, International Letters of Social and Humanistic Sciences 2 (2013) 56-60.

[6] M. Oliwa Ciesielska, Praca Socjalna 3 (2002) 63.

[7] R. Majer, Katalog Domów Pomocy Społecznej, Częstochowa, 2002.

[8] A. Borowski, International Letters of Social and Humanistic Sciences 1 (2013) 14-18. 